Meta

Journal des traducteurs

Translators' Journal

\title{
To Be or Not to Be Natural: Clichés of Emotion in Screen Translation
}

\section{Vera Lúcia Santiago Araújo}

Volume 49, numéro 1, avril 2004

Traduction audiovisuelle

Audiovisual Translation

URI : https://id.erudit.org/iderudit/009031ar

DOI : https://doi.org/10.7202/009031ar

Aller au sommaire du numéro

\section{Éditeur(s)}

Les Presses de l'Université de Montréal

\section{ISSN}

0026-0452 (imprimé)

1492-1421 (numérique)

Découvrir la revue

\section{Citer cet article}

Santiago Araújo, V. (2004). To Be or Not to Be Natural: Clichés of Emotion in Screen Translation. Meta, 49(1), 161-171. https://doi.org/10.7202/009031ar
Résumé de l'article

L'objectif de cet article est de présenter les résultats de ma thèse de doctorat, portant sur la traduction de clichés de l'anglais américain vers le portugais du Brésil, à partir de cinq films doublés et sous-titrés. Les clichés, nommés aussi expressions toutes faites ou figées, sont des formules employées par les locuteurs d'une certaine langue, au point où elles en sont devenues stéréotypes et lieu commun. Plus de 250 clichés exprimant l'émotion ont été trouvés dans notre corpus. Nous avons cherché à décrire les normes qui régissent les manières de les traduire au Brésil. L'une d'elle ressort nettement de notre analyse : l'absence de spontanéité, c'est-à-dire que les traducteurs retiennent quelquefois une expression qui n'est pas naturelle en portugais. Un tel choix s'explique certainement par les contraintes de la traduction audiovisuelle et aussi par le désir des traducteurs de produire une traduction fidèle. 


\title{
To Be or Not to Be Natural: Clichés of Emotion in Screen Translation
}

\author{
VERA LÚCIA SANTIAgo ARAÚJO \\ Satate University of Ceará, Fortaleza, Brazil \\ verasant@uece.br
}

\begin{abstract}
RÉSUMÉ
L'objectif de cet article est de présenter les résultats de ma thèse de doctorat, portant sur la traduction de clichés de l'anglais américain vers le portugais du Brésil, à partir de cinq films doublés et sous-titrés. Les clichés, nommés aussi expressions toutes faites ou figées, sont des formules employées par les locuteurs d'une certaine langue, au point où elles en sont devenues stéréotypes et lieu commun. Plus de 250 clichés exprimant l'émotion ont été trouvés dans notre corpus. Nous avons cherché à décrire les normes qui régissent les manières de les traduire au Brésil. L'une d'elle ressort nettement de notre analyse: l'absence de spontanéité, c'est-à-dire que les traducteurs retiennent quelquefois une expression qui n'est pas naturelle en portugais. Un tel choix s'explique certainement par les contraintes de la traduction audiovisuelle et aussi par le désir des traducteurs de produire une traduction fidèle.
\end{abstract}

\section{ABSTRACT}

The objective of this article is to report the results of my Doctoral thesis that investigated the translation of American English clichés into Brazilian Portuguese in five dubbed and subtitled films. Clichés, also called situational or routine formulas, are those expressions used by speakers of a certain language which have become stereotyped and commonplace due to repetitive use. More than 250 clichés expressing emotion were found in the corpus. The study aimed at the description of the norms that regulated Brazilian translators' rendering of the clichés. The analysis revealed that one norm governed the translation, that of absence of naturalness. That is, the translator sometimes chose an expression which is not natural in Portuguese. This was mainly due to the constraints of the audiovisual setting and the translator's wish to produce a 'faithful' translation.

\section{MOTS-CLÉS/KEYWORDS}

clichés, dubbing, norms, screen translation, subtitling

\section{Introduction}

Screen translation is a very prominent activity in Brazil, as many foreign films are shown through cinema, home video and television. The most common modes of translation used are dubbing and subtitling. In open TV dubbing is preferred, whereas in cable TV both methods appear. Subtitling prevails in the cinema, where dubbing is restricted to children's films. Such a vast amount of audiovisual productions to render demands a lot of effort on the part of the translators, because, at least in $\mathrm{TV}$ and home video translations, they do not have much time to do their job. As a consequence, they have to face all the difficulties involved in their work very quickly. One of these problems is dealing with the language present in foreign productions, especially the expressions which are very specific to a certain culture. 
Clichés, also called situational or routine formulas, formulaic speech, stereotyped expressions, conversational or linguistic routines, among others, are those expressions used by speakers of a certain language which have become stereotyped and commonplace due to repetitive use (Tagnin, 1989: 57). Quotations, set phrases and proverbs are those which most commonly appear as clichés. Cliché expressions have lost their original meaning, acquiring a function in social interactions and communication. For example, the expression God bless his soul does not mean what it used to, that is, it is not just about someone asking God to bless a person's soul. Nowadays, this expression is mainly used to refer to the dead. People do not even think of God's blessing when they are saying it. It essentially indicates that the person we are talking about is no longer among the living. Zijderveld (1979: 10) says that the cliché "stimulates behaviour (cognition, emotion, volition, action), while it avoids reflections on meaning." In other words, the author says that whenever a cliché is used there is a "supersedure of meaning by function."

Oral language expressions are very frequent in our daily conversations and reflect our cultural experience. As a consequence, some of them are very typical of a certain community. Film dialogues, being a simulation of oral conversation, are full of such expressions and their translation may cause a lot of difficulties to subtitling and dubbing translators.

This article aims at reporting the results of my Doctoral thesis that investigated the translation of American English clichés into Brazilian Portuguese in dubbed and subtitled films made for home video and television. Since there are different kinds of clichés, which would make a comprehensive analysis difficult, I chose to analyze those expressing emotion.

Five American films - War of the Roses (1989), Mrs. Doubtfire (1993), Bye, Bye, Love (1995), First Wives Club (1996), and Home Arrest (1996) - were selected because they dealt with divorce, a subject that triggered a lot of distinct kinds of emotions. More than 250 clichés expressing love, joy, anxiety, sympathy, guilt, sorrow, anger, surprise, and irony were found in the corpus. The rendering of these clichés in Portuguese was analysed, considering the different kinds of constraints faced by film translators. The aim of the study was the description of the norms that regulated translators' rendering of the clichés. The main hypothesis to be tested was that some expressions were translated literally and were not natural choices of Brazilian Portuguese speakers in that specific situation.

\section{Film translation in Brazil}

As the limitations of screen translation were considered in the analysis, it is relevant to discuss the elements which affect its production. Only lip sync dubbing and subtitling will be mentioned here, because they were the methods of translation used to translate the five films. A brief description of their mechanics will be given, in order to show their influence in the translation.

Lip sync dubbing involves teamwork performed by different professionals. First, the translator is given a time-coded tape (a working copy equipped with a time code reader or TCR) and the dialogue list. Then, the dubbing director selects the cast of dubbing actors and the recording is done. Finally, the editor mixes and edits the new voices. According to Luyken et al. (1991: 74), the task of dubbing translator in Europe 
is done by three different professionals and follows three stages and may be done by three different professionals: spotting, raw translation and adaptation. The spotting is the indication of the "beginning and end of timecodes of each enunciation." The raw translation is the rewriting of the dialogue list in the target language, but without adapting the translated text into the lip movements of the original. This adaptation will be done later by a screenwriter. In Brazil, dubbing translation is the sole responsibility of the dubbing translator. S/he is the one who spots the film, observes the lip movements of the original text and synchronizes it with the translated text. S/he must also indicate in which page of the dialogue list each character appears, in order to guide the work of the director and the performance of the actors. This is called "dubbing mirror" in the dubbing jargon.

Naturally, the fact that the text can be modified by translators, actors and directors has a lot of implications for the translation. The text produced by the translator may not suit the lines of a specific character and the director and actors adapt it for dubbing. But not only these people influence the process of translation, the distributor, the dubbing studio owner, the critics and the audience also must be taken into consideration before the translation is released. So, it is not possible to analyze this kind of translation without considering these limitations imposed by the audiovisual setting.

Like dubbing, subtitling has its own constraints. While in dubbing, lip sync is the main limitation, in subtitling space and time mandates. The diagram below proposed by Alvarenga (1998) shows the mechanics of subtitling for TV and home video in Brazil:

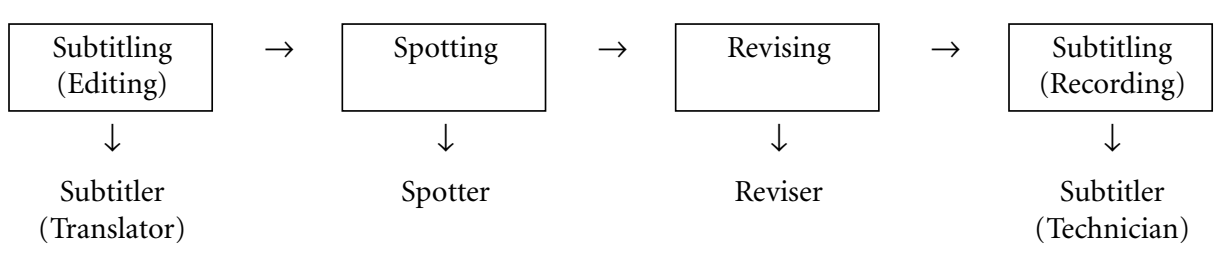

Brazilian subtitling companies usually do not give the translators access to subtitling software. Instead, they instruct them to make a kind of simulation of this software by using an ordinary computer programme, like Microsoft Word, font Times New Roman, size 10. The translators are asked to regulate the Microsoft Word to a certain size, so as to imitate the subtitling software format. So, subtitlers with the help of the TCR, spot the beginning and the end of the titles "virtually" and type them in a format which is an approximation of the subtitling programme. An example of the translation of a sequence of Mrs. Doubtfire (1993) is shown below. The sequence has four titles. The first is a translation of a three-second speech and the subtitler has about 45 characters to carry out the task. The second is a dialogue spoken in approximately $1.5 \mathrm{~s}$ (about 15 characters). The third and fourth were one-second titles (about 16 characters). The format (size 4.75, left aligned) would be the following:

Those who don't follow the schedule, will be punished.

- Punished?

- She's lying
Quem não seguir o

horário será punido.

- Punido?

- Ela está mentindo. 
She would never punish us.

Don't fuss with me!
Ela nunca nos puniria.

Não se meta comigo.

The spotting is done by another professional. The spotter is not a professional translator and, in most cases, does not know the foreign language. Yet, s/he is allowed to change any translation which does not fit the software specifications. As a consequence, the subtitler tries to be as accurate as possible so that his choices are not changed. After spotting, the text is revised by someone who may not be aware of the nature of this kind of text, like a Brazilian Portuguese teacher, for example. However, some subtitling companies eliminate this stage when they deal with a very experienced subtitler.

When the text is finally translated, spotted and revised the titles are recorded (the term currently used is "burned") on the tape. This job is done by a technician who, like the spotter, may not understand the foreign language, but can make any changes needed in the text. As we can see, subtitling is also teamwork, and this fact can affect the translation a lot, not to mention other factors the subtitler has to handle (linguistic aspects, time-character relationship, high degree of condensation and omission, and speech-image-title synchronism).

All these constraints made Luyken et al. (1991: 153-5) wonder if screen translation can really be given the status of translation. They point out pieces of evidence to try to prove their point. First, they say that translation is the replacement of a certain message and/or statement in one language by the same message and/or statement in another language. The message of an audiovisual text is formed by a whole composed of image, sound, language, and actors' performance, among other elements. The two modes of screen translation would alter only one of these elements, dubbing, the sound, and subtitling, the language. Second, an audiovisual text cannot be rendered literally, as it needs to be "interpreted" all the time. Third, an audiovisual text, once translated, is usually shorter than the original; sometimes it has to be modified in order to be appreciated by a certain audience.

Even though Luyken et al.'s arguments are based on a view not shared by most translation researchers nowadays, they discuss very relevant aspects concerning the translator's task and distinguish conventional translators from screen translators:

Every translator must have a profound understanding of the nuances of the source language, a good writing skill in the target language (which is usually his or her mother tongue) and a detailed knowledge of the culture of the country or countries in which the source language is spoken. The Language Transfer worker or team, however, must have all of these qualities and, in addition, an empathy with the new audience and an understanding of the audiovisual media. The Language Transfer worker must be able to discern what television viewers do or do not require in the way of additional information in order to understand and enjoy the programme. In Language Transfer, more than in conventional translation, there is a need for an accurate appreciation of the knowledge which the audience might be expected to have or not to have.

In my opinion, what they say about screen translation is true to all kinds of translation. Recent studies show that translation not only deals with linguistic aspects, but also with other elements (context, target audience and target culture), as they affect the final result. So, all kinds of translators are bound to face many different constraints, but for the screen translators these limitations are more visible. 


\section{The clichés of emotion}

After being collected, the clichés were organised in data record files containing relevant information for their description and analysis, such as function, context, and translation, among other information. They were then categorized, according to the emotion they expressed. Some examples of these clichés can be seen below (the films will be identified by the following notations: Mrs. Doubtfire (F1), Home Arrest (F2), Bye, Bye, Love (F3), First Wives Club (F4), War of the Roses (F5):

\section{a) anger}

More than 60 occurrences of this category were found. The characters expressed their anger by means of insults, threats and swear words: Don't you dare (F1), God damn you, Dumb bastard, Stinking bitch (F5).

b) anxiety

The anxiety clichés show how anxious and relieved some of the characters were: She's gonna kill me (F2), Thank God (F3), (F4), (F5), Oh Shit (F1), What's wrong? (F4).

c) guilt

Here we have different variations of the same cliché: This is all my fault (F1), It was my fault (F2).

d) irony

Even though irony cannot be considered an emotion, some emotion clichés found in the corpus were used ironically. For example, Be my guest (F4) is not a polite request, but a response to a threat by saying that one is not afraid. Other examples are: Are you kidding? (F1), Don't bother (F5), Look who's here (F3).

e) joy

The aim of the characters was to be polite, show how happy they were in seeing someone, make a compliment or indicate they were in a good mood: It's a pleasure to see you again (F1), I'm so happy to see you (F3), You look great (F4), What a lovely day (F2).

f) love

This category includes the clichés in which the characters demonstrate their affection for one another: I love you, I cherish you (F4), That's my girl, Look how sweet she is (F3).

g) sorrow

Sorrow clichés were very common in the corpus. They showed the way parents and kids feel during a divorce: Don't ask (F1), I really am sorry, Good old days (F3), It's all over (F4).

h) surprise

Some examples of positive (better-than-expected situation) and negative (contraryto-expected situation) surprise were observed (Kryk-Kastovsky, 1997: 158). Some of these clichés were: Look at this, Look at this place (F1) (positive surprise), This is absurd (F5), Oh my God (F4) (negative surprise).

i) sympathy

Sympathy for other people's pain was displayed in 45 clichés, such as: Stay calm, What's wrong? (F4), Everything is gonna be fine (F3), Hang in there (F5). 


\section{The translation of clichés}

The study aimed at searching the norms that governed the translation of clichés of emotion in screen translation. In order to do this, the strategies used by screen translators in rendering these clichés were examined to confirm or reject the hypothesis that the translations were not natural. The analysis inferred that Brazilian translators used five strategies to meet the demands involved in their task.

Four strategies showed that the absence of naturalness is the norm:

a) the creation of grammatically correct expressions, which do not sound nativelike in Portuguese;

b) the translation of clichés into some expressions that are not clichés in Brazilian Portuguese;

c) the minimisation of taboo words;

d) the use of formal language in subtitling, which does not suit the oral aspect of a film dialogue. This behaviour was mainly caused by the translator's wish to produce a faithful translation. This search for literality was influenced by the pressure exerted by film distributors, subtitling companies, dubbing studios, other professionals involved in film translation, television and home video viewers, and film critics, who want translations to be as close to the original text as possible.

The first strategy revealed that translators tended to create new expressions, that according to Pawley and Syder (1983: 193) were grammatical but unnatural:

The problem we are addressing is that native speakers do not exercise the creative potential of syntactic rules to anything like their full extent, and that, indeed, if they did so they would not be accepted as exhibiting nativelike control of the language. The fact is that only a small proportion of the total set of grammatical sentences are nativelike in form - in the sense of being readily acceptable to nativelike informants as ordinary, natural forms of expression, in contrast to expressions that are grammatical but are judged to be 'unidiomatic,' 'odd' or 'foreignisms.'

However, the fact that the new expressions are grammatical does not eliminate the possibility that they will become a cliché in Portuguese, due to their repetitive use. The analysis considered that these expressions may not be natural at the moment, but may become so in the future.

This happened to skeletons in the cupboard (esqueletos no armário), which appeared in the subtitled version of Four Weddings and a Funeral (1994). The translation was highly criticised by a weekly magazine article, saying that the subtitler had made a "mistake." The argument was lack of equivalence and unfaithfulness on the part of the translator. Believing that there is a one-to-one equivalence between languages, the article said the translator did not use the "right" expression, preferring a "literal" translation. What they call "literal" is, in fact, their interpretation of what is "correct" in the context of the film. It is obvious that the use of such "literal" expressions is strange to us, Brazilian Portuguese speakers, but it is dangerous to talk about mistakes, because these translator-created expressions may in the long run be used routinely, as is the case of esqueletos no armário which was seen in two other articles later published in the same magazine. The first article is about the period of the military government in Brazil which, according to the reporter, is still a skeleton in the cupboard of the country (1998). The second shows a fashion designer who keeps real skeletons in his cupboards, because they provide inspiration for his work (he 
designs skeletons on T-shirts). However, in spite of the "literal" use, we can perceive the reference to the English expression. This expression is now highly used in the Brazilian press, and it does not cause the same kind of response it once did. One could say that it is becoming a cliché in Brazilian Portuguese.

Bamba (1996: 03) claims that expressions deemed strange to target language viewers often appear in the subtitling text, for this kind of translation demands a lot of adaptation on the part of the translator who, as a consequence, thinks it safer to remain closer to the source language. In other words, subtitlers tend to create expressions in the target language which are very similar to the ones in the source language. The rendering of That would make my day (F1) is a good example of one of these expressions. It was translated by Ia fazer o meu dia in the subtitled version (SV from now on), instead of Aí, sim, eu ganhava o dia (I would win the day), more common in this kind of situation. Nowadays we can say that a Brazilian would hardly understand such an expression. However, the two dubbed versions (DB from now on) used two different expressions which are not clichés, but they would not be as strange as the one used in SV: Isto completaria o meu dia (That would complete my day), Isto ia alegrar o meu dia (That would cheer up my day). But in spite of the strangeness of Ia fazer o meu dia, one never knows if it will ever become a cliché in Brazil.

The table below points out some of these created expressions. It also shows what would be the natural choices in that specific situation for Brazilian Portuguese speakers. Most of them were taken from other translations in the corpus, except for the translation of How tragic, in which all versions used the unnatural translation:

\begin{tabular}{|l|l|l|}
\hline Expression in English & Unnatural Translation & Brazilian Portuguese cliché \\
\hline How tragic (F1) & Que trágico (SV, DV1, DV2) & Que tragédia (What a tragedy) \\
\hline Don't ask (F1) & $\begin{array}{l}\text { Que adorável (SV), } \\
\text { Que bonito (SV) }\end{array}$ & $\begin{array}{l}\text { Nem fala (Don’t even talk to me) } \\
\text { (DV2) }\end{array}$ \\
\hline How lovely (F1) & $\begin{array}{l}\text { Que ótimo (How nice) (DV1) } \\
\text { Que beleza (How beautiful) (DV2) }\end{array}$ \\
\hline God bless his soul (F1) & $\begin{array}{l}\text { Que abençoe a sua alma } \\
\text { Que Deus o tenha (May God } \\
\text { keep him) (SV) } \\
\text { Que ele descanse em paz } \\
\text { (May he rest in peace) (DV1) }\end{array}$ \\
\hline May he rest in peace (F3) & $\begin{array}{l}\text { Que fique em paz } \\
\text { (May he be in peace) }\end{array}$ & $\begin{array}{l}\text { Que ele descanse em paz } \\
\text { (May he rest in peace) (DV) }\end{array}$ \\
\hline
\end{tabular}

The second strategy of translation is closely related to the previous one, as it involves that kind of situation in which there is a strong expectation of a cliché. This situation is so hackneyed that not using a cliché is very strange. Unlike the previous case, the main reason for not using a cliché may not be the search for literality. The aspect affecting the translation was technical. For the sake of lip movement synchronism, dubbing used non-cliché expressions in their translations. For example, the rendering of Go for it into Reaja (React) and not into Vá em frente (Go ahead) or Vá à luta (Go fight for it). Below, some more examples: 


\begin{tabular}{|l|l|l|}
\hline Expression in English & Unnatural Translation & Brazilian Portuguese cliché \\
\hline Give me five (F1) & $\begin{array}{l}\text { Bate aqui (Slap here) } \\
\text { (SV, DV1) }\end{array}$ & Toca aqui (DV2) \\
\hline Don't be silly (F3) & $\begin{array}{l}\text { Não faz isso não } \\
\text { (Don't do this) (DV) }\end{array}$ & Não seja bobo (SV) \\
\hline $\begin{array}{l}\text { Everything is gonna } \\
\text { be fine (F3) }\end{array}$ & $\begin{array}{l}\text { Isso vai dar certo (This is } \\
\text { gonna be all right) (DV) }\end{array}$ & Vai dar tudo certo (SV) \\
\hline Don't you dare (F4) & $\begin{array}{l}\text { Não faça isso não } \\
\text { (Don't do this) (DV) }\end{array}$ & Não se atreva (SV) \\
\hline I wish I could (F4) & Eu gostaria (I'd love to) (DV) & Quem me dera (SV) \\
\hline
\end{tabular}

The third strategy involves the translation of taboo words. In both subtitled and dubbed versions they are minimized, because of pressures exerted by film distributors. They claim that their audience would not like to "hear" or "read" swear words. As a consequence, subtitling companies and dubbing studios instruct translators to minimize them by using words which are not offensive to the audience, especially the open TV viewers. This attitude on the part of the distributors gives the impression that foreign films have no swear words, while Brazilian productions are full of them. However, this situation is beginning to change, as cinema and some home video translations are starting to use natural swear words in Brazilian Portuguese. For instance, they might not translate Fuck you, Shit, and Son of a bitch by Vá se danar, Droga and Filho da mãe, respectively. Instead, they would be allowed to use the natural choices of a Brazilian native speaker in this context (Vá se foder, Merda or Filho da puta).

Some other examples of this minimization are:

\begin{tabular}{|l|l|l|}
\hline Expression in English & Unnatural Translation & Brazilian Portuguese cliché \\
\hline Screw the world (F4) & $\begin{array}{l}\text { Dane-se o mundo } \\
\text { (Damn the world) (SV, DV) }\end{array}$ & Foda-se o mundo. \\
\hline Piss off (F1) & $\begin{array}{l}\text { Vá se danar (Damn you) (SV), } \\
\text { Vá tomar banho (You take } \\
\text { a shower) (DV1), Dane-se } \\
\text { (Damn you) (DV2) }\end{array}$ & Vai se foder. \\
\hline Stinking bitch (F5) & $\begin{array}{l}\text { Vaca fedorenta (stinking cow) } \\
\text { (SV), Sua desgraçada (DV) } \\
\text { (You idiot) }\end{array}$ & Sua puta. \\
\hline Slut (F5) & $\begin{array}{l}\text { Piranha (Tart) (SV), Cadela } \\
\text { (Female dog) (DV) }\end{array}$ & Sua puta. \\
\hline Fuck face (F5) & $\begin{array}{l}\text { Droga (Damn you) (SV), } \\
\text { Palhaço (Clown) (DV) }\end{array}$ & Seu porra. \\
\hline
\end{tabular}

The fourth and last strategy that proves the hypothesis that the unnaturalness norm prevails in the rendering of clichés refers to language usage. It is applied more to subtitling than to dubbing. Although some instances were found in dubbing, it was in subtitling that formal language appeared more frequently. This may be explained by the fact that subtitling is exhibited in the form of written language, which makes the 
professionals involved believe that it must follow the same rules of written language. Even if subtitlers view the situation differently, it is hard to convince distributors and subtitling companies that the language used to translate a film is usually colloquial.

Dubbing, on the other hand, does not face this difficulty, as it is the oral translation of an oral text. Consequently, the renderings are more natural, as dubbing translators are encouraged to use colloquial language. Moreover, it would be strange for the actors and directors to dub a text in which formal language prevails. Some grammatical aspects suggest the formalism of subtitling and the colloquialism of dubbing. There follow some examples of these aspects.

- The position of the object pronoun in the sentence

Brazilian and European Portuguese differ considerably as to the position of the object pronoun in the sentence. For the Europeans, this pronoun always follows the verb in either oral or written Portuguese. For us Brazilians, it is true only in written language, as we tend to place the object pronoun differently when speaking. In other words, in spoken Brazilian Portuguese the pronoun precedes the verb. This is the case of the translation of Leave me alone (F3). It would be odd for a Brazilian teenage girl to say Deixe-me em paz, instead of the colloquial Me deixe em paz.

Sometimes subtitlers try to find alternatives to these non-colloquial expressions by replacing them with other expressions. These expressions are based on the source language and, as was already mentioned, the result is still unnatural, as the following table shows:

\begin{tabular}{|l|l|l|}
\hline Expression in English & Unnatural Translation & Brazilian Portuguese cliché \\
\hline Back off (F1) & Para trás (SV) & Se manda (DV1, DV2) \\
\hline I really am sorry & Sinto muitíssimo (SV) & Me desculpe (DV) \\
\hline
\end{tabular}

- The alternation of the subject pronouns Tu (you) and Você (you, second person singular conjugated as third)

This is another grammatical aspect which is typical of Brazilian Portuguese. While exchanging Tu and Você is not advisable in writing, it is highly expected in speaking. So, when addressing someone, Brazilians tend to alternate the use of the two pronouns (Esquece tu ou Esqueça você (Forget it)). This kind of alternation cannot be heard in Portugal, where the pronoun most commonly heard is Tu. Subtitling, in order to avoid such a mistake, uses only Você, while dubbing alternates the two pronouns:

\begin{tabular}{|l|l|l|}
\hline Expression in English & Unnatural Translation & Brazilian Portuguese cliché \\
\hline Forget it (F3) & Esqueça (SV) & Esquece $(\mathrm{Tu})(\mathrm{DV})$ \\
\hline $\begin{array}{l}\text { It was good to see } \\
\text { you again (F1) }\end{array}$ & Foi bom revê-la $(\mathrm{SV})$ & $\begin{array}{l}\text { Bom ver você }(\mathrm{Você})(\mathrm{DV}) \\
\text { Bom te ver }(\mathrm{Tu})\end{array}$ \\
\hline
\end{tabular}

- The usage of the reduced forms of the verb Estar (to be) and the preposition Para (at, for or to)

As these grammar features appear in colloquial language, they can only be observed in dubbed versions: 


\begin{tabular}{|l|l|l|}
\hline Expression in English & Unnatural Translation & Brazilian Portuguese cliché \\
\hline She looks wonderful (F4) & Ela está maravilhosa (SV) & $\begin{array}{l}\text { Ela tá ótima (DV1) } \\
\text { Ela tá poderosíssima (DV2) }\end{array}$ \\
\hline Look at her (F3) & Olhem para ela (SV) & Olhem pra ela (DV) \\
\hline
\end{tabular}

- The usage of the subject pronoun as a complement and the use of $A$ gente replacing Nós (we).

Using the subject pronoun in object position and the expression A gente are regarded as grammatical mistakes in written, but not in spoken language, where they are largely used. Again, they can be found in dubbed versions but not in subtitled ones:

\begin{tabular}{|l|l|l|}
\hline Expression in English & Unnatural Translation & Brazilian Portuguese cliché \\
\hline I'll kill him (F3) & Eu o mato (SV) & Eu mato ele (DV) \\
\hline $\begin{array}{l}\text { We should see each } \\
\text { other more (F3) }\end{array}$ & Devíamos nos ver mais (SV) & A gente devia se ver mais (DV) \\
\hline
\end{tabular}

We should emphasize that the choices mentioned here were made not only for the reasons pointed out. For instance, the reason why the second cliché mentioned above is unnatural might have been the speech-title-image synchrony, instead of the avoidance of the colloquial $A$ gente. This is true of all the other strategies previously discussed. However, regardless of the cause, the most relevant aspect of this study is that it reinforces the need to examine the factors affecting screen translation in order to carry out research in this area.

\section{Conclusion}

The Doctoral research reported here investigated the translation of 250 clichés into Brazilian Portuguese to find out the translational behaviour of Brazilian screen translators, concerning the rendering of these clichés. The analysis showed that translators tended to use non-cliché expressions due to the constraints of the audiovisual environment. However, when these limitations allowed, some natural translations were produced as the study indicated that 143 clichés are in this situation.

In conclusion, I hope this research is a contribution to the discussion on the translation of clichés in audiovisual productions. Perhaps the results will be of use as a reference for screen translators. It is my intention to transform them into a glossary, giving suggestions for the rendering of clichés, considering lip movement and speech-title-image in dubbing and subtitling, respectively.

\section{REFERENCES}

Alvarenga, L. (1998): “Subtitler: legendador ou legendista?" Proceedings of the ICIATI, Congresso ibero-americano de tradução e interpretação, São Paulo, Brazil, May, pp. 214-216.

Araújo, V.L.S. (2000): Ser ou não Ser Natural, Eis a Questão dos Clichês de Emoção na Tradução Audiovisual, Unpublished Doctoral Thesis, São Paulo, University of São Paulo.

Bamba, M. (1997): Da Interação da Língua Falada com a Lingua Escrita a Outras Formas de Interação Semiótica na Geração de Texto de Legendas de Filmes, Unpublished MA Dissertation, São Paulo, University of São Paulo. 
Kryk-Kastovsky, B. (1997): "Surprise, Surprise: the Iconicity-Conventionality Scale of Emotions" in S. Niemeier and R. Dirven (eds.) The Language of Emotions. Amsterdam/ Philadelphie, John Benjamins, pp. 155-169.

Luyken, G.M. et al. (1991): Overcoming Language Barriers in Television. Dubbing and Subtitling for the European Audience, Manchester, The European Institute for the Media.

Pawley, A. and F.H. Syder (1983): "Two Puzzles for Linguistic Theory: Nativelike Selection and Nativelike Fluency" in J. Richards and R. Schmidt (eds.) Language and Communication, London, Longman, pp. 191-226.

TAgnin, S.E.O. (1989): Expressões Idiomáticas e Convencionais. São Paulo, Ática.

Zijderveld, A. (1979): On Clichés. The Supersedure of Meaning by Function in Modernity. London, Routledge and Kegan Paul. 